Potravinarstvo Slovak Journal of Food Sciences vol. 15, 2021, p. 835-845

https://doi.org/10.5219/1651

Received: 12 June 2021. Accepted: 17 September 2021. Available online: 28 September 2021 at www.potravinarstvo.com (C) 2021 Potravinarstvo Slovak Journal of Food Sciences, License: CC BY 4.0

ISSN 1337-0960 (online)

\title{
REMNANT PHOTOSYNTHETIC PIGMENTS IN TEA DREGS: IDENTIFICATION, COMPOSITION, AND POTENTIAL USE AS ANTIBACTERIAL PHOTOSENSITIZER
}

\author{
Renny Indrawati, Elok Zubaidah, Aji Sutrisno, Leenawaty Limantara, \\ Tatas Hardo Panintingjati Brotosudarmo
}

\begin{abstract}
The production of tea dregs is continually increasing along with the growth of people's interest in ready-to-drink beverages. However, the recent development of research on the use of tea dregs is still very limited. The present study was aimed to identify the remnant photosynthetic pigments in tea dregs, determine their composition, and evaluate their potential use as natural antibacterial agents based on light-induced reaction (photosensitization). The tea dregs from six commercial teas, consisting of green and black teas, were analyzed using high-performance liquid chromatography (HPLC) with a photodiode array detector, and the spectroscopic data were analyzed from 350 to $700 \mathrm{~nm}$. Pigment identification was performed based on spectral characteristics, and pigment composition in the extracts from the dregs was determined by a three-dimensional multi-chromatogram analysis method. The dominant pigment fractions in both tea types were pheophytin $a$ and its isomers, as well as pheophytin $b$. Although the dregs of black teas generally contain fewer remnant pigments, they possess residual chlorophyll $b$, which is not found in the dregs of green teas. In thirty-minutes illumination under $50 \mathrm{~W}$ red light-emitting diode, the presence of pigments from tea dregs caused up to 0.87 and $0.35 \mathrm{log}$ reduction of Staphylococcus aureus and Escherichia coli, respectively. The disparity of pigments composition among tea types does not strongly influence their photosensitization activity against both bacteria. Hence, upon further application, the amount of total remnant pigments in the dregs could be taken as substantial consideration instead of tea types.
\end{abstract}

Keywords: antimicrobial photosensitization; chlorophyll; pigments; tea dregs

\section{INTRODUCTION}

Besides drinking water, tea is the most favored beverage consumed by at least $65 \%$ of people worldwide (Diby et al., 2017). Tea beverages are prepared through the infusion of dried leaves of Camellia sinensis (L.) to extract therapeutic compounds, mainly polyphenols, as well as aromatic compounds (Rodrigues et al., 2015; Chaturvedula and Prakash, 2011). The remaining insoluble material is called tea dregs, which can be utilized as feed, fertilizer, or adsorbent (Chowdhury et al., 2016; Kabir et al., 2021). The global market of ready-to-drink tea beverages has continually increased, with a demand of 18 to 20 billion cups of tea per day, and this inevitably impacts the massive production of dregs and improper disposal (Dubey et al., 2020; Hussain et al., 2018).

The other important metabolites in tea leaves are the group of non-polyphenolic pigments, chlorophylls, and carotenoids, which have an important role in capturing light energy for photosynthesis in tea plants. During tea manufacture, these pigments are disrupted into their derivatives as a result of the processing conditions, such as heat, light, and dehydration, as well as enzymatic reactions (Wei et al., 2020; Roshanak, Rahimmalek, and Goli, 2016). This molecular alteration often determines thecolor, type, and quality of the tea (Wei et al., 2021; Chaturvedula and Prakash, 2011). Nevertheless, these pigments have poor solubility in water during tea infusion and allegedly remain in the dregs (Donlao and Ogawa, 2019). At the time of writing, most studies in the literature provide only data about the total amount of chlorophylls in tea through spectroscopic estimation. Few reports have specifically characterized pigment derivatives in the processed teas (Suzuki and Shioi, 2003; Yu et al., 2019), but none has detailed complete pigment composition in the dregs.

Chlorophyll derivatives have been targeted as potential natural photosensitizers for food disinfection (Gerola et al., 2011; Ghate, Zhou, and Yuk, 2019). Chlorophyll derivatives have the absorption band at the red region (625 $-700 \mathrm{~nm}$ ). Upon light absorption, the excited energy can be transferred to $\mathrm{O}_{2}$ molecules through triplet-triplet (T-T) energy transfer, and make oxygens become radical species. Such radicals are cytotoxic and able to induce the rapid 
inactivation of pathogens (Indrawati, Lolita, and Limantara, 2021). Most investigations used derivatives that were artificially modified from naturally occurring chlorophylls (Kustov et al., 2018; Zhang et al., 2019; Oktavia, Mulyani, and Suendo, 2021). However, natural sources of chlorophyll derivatives would be favored by consumers in food-related products.

Therefore, the present study aimed to (i) identify the photosynthetic pigments that are present in the dregs of teas, determine the composition of remnant pigments, and (ii) evaluate their potential use for bacterial inactivation through photosensitization. The content of pigments in the dregs was compared among several commercial green and black teas. Pigment separation and identification were performed using high-performance liquid chromatography (HPLC) and a diode array detector. The three-dimensional (3D) multi-chromatogram method was adopted to determine the distribution of pigments in a fast and accurate way (Indrawati et al., 2012; Brotosudarmo et al., 2018; Indrawati et al. 2019). Furthermore, the antimicrobial effect upon light induction was verified against Staphylococcus aureus and Escherichia coli.

\section{Scientific hypothesis}

The study on pigment identification and composition was carried out as descriptive research, whereas the assay of antimicrobial photosensitization was conducted in an experimental framework. The proposed hypotheses were the following: (i) illumination causes a significant effect on the number of viable bacteria treated with dregs extract, and (ii) dregs extract from green and black teas have a different effect on the percentage of photosensitized inactivation.

\section{MATERIAL AND METHODOLOGY Samples}

Six commercial teas were purchased from local supermarkets in Malang, Indonesia. The samples are three green teas (GT) and three black teas (BT), which belong to local tea products in Indonesia. The sample code, brand, and manufacturing factory are listed in Table 1.

Table 1 The identity and code of the tea samples.

\begin{tabular}{lll}
\hline Code & Brand & Manufacturing Factory \\
\hline GT1 & Sariwangi & PT Unilever Indonesia \\
GT2 & Teh Jawa & PT Sari Melati Sejahtera \\
GT3 & Kepala & PT Gunung Subur \\
& Djenggot & Sejahtera \\
BT1 & Sariwangi & PT Unilever Indonesia \\
BT2 & Teh Jawa & PT Sari Melati Sejahtera \\
BT3 & Sosro & PT Sinar Sosro \\
\hline
\end{tabular}

\section{Chemicals}

The chemicals used in pigment extraction and liquid chromatographic analysis were acetone, methanol, acetonitrile, and pyridine (Merck KGaA, Darmstadt, Germany, pro-analysis grade). The pigment standard (pheophytin $a$, chlorophyll $b$ ) was obtained from NatChrom $^{\circledR}$ (Malang, Indonesia). The experiments with microorganisms used Tween-80 (Sigma- Aldrich, France, $\geq 58.0 \%$ oleic acid) and microbiological media (nutrient broth, Mueller-Hinton broth, trypticase soy agar, buffered peptone water) from Merck KGaA (Darmstadt, Germany).
Aldrich, France, $\geq 58.0 \%$ oleic acid) and microbiological media (nutrient broth, Mueller-Hinton broth, trypticase soy agar, buffered peptone water) from Merck KGaA (Darmstadt, Germany).

\section{Biological Material:}

The antibacterial assay used Staphylococcus aureus ATCC 6538 and Escherichia coli ATCC 8739, acquired from the Department of Pharmacy, Widya Mandala Catholic University, Surabaya, Indonesia.

\section{Instruments}

The analytical instruments used in this study were a UVvisible spectrophotometer (UV-1800, Shimadzu, Kyoto, Japan), an ultra-fast liquid chromatography instrument (LC20A with an SPD-20MA diode array detector, Shimadzu, Kyoto, Japan) with a C8 column (Waters, Massachusetts, USA) for the separation of photosynthetic pigments, and an HPLC-UV/Vis detector (Agilent Technologies, Waldbronn, Germany) for the determination of polyphenol residues. The equipment used in the photosensitization experiments included a quantum meter (Apogee Instrument, MQ-200, USA) for measuring light photons, an orbital shaker (MaxQ 2000, Thermo Scientific, Iowa, USA), and a red LED lamp (Yomiko YL-2550, $50 \mathrm{~W}$, peak emission at $640 \mathrm{~nm}$ ).

\section{Laboratory Methods}

\section{Preparation of tea dregs and pigment extraction}

Each tea sample was subjected to the hot infusion $\left(90^{\circ} \mathrm{C}\right)$ for 5 and $20 \mathrm{~min}$ at a tea-to-water ratio of 1:100 (w/v). The dregs were then separated after filtration and dried overnight at room temperature to reduce their water content. Pigment extraction was carried out in acetone at a dregs-tosolvent ratio of 1.5:10 (w/v). The extraction was repeated twice until the pellet turned pale. The acetone was subsequently removed by vacuum evaporation, and the pigments were stored in an inert gas $\left(\mathrm{N}_{2}\right)$ in amber vials at a low temperature $\left(-20^{\circ} \mathrm{C}\right)$ until the time of analysis. The whole extraction procedure was completed under dim light to avoid any possible degradation of pigments.

\section{HPLC separation}

The pigments were first redissolved in acetone, and then an aliquot $(20 \mu \mathrm{L})$ was injected into the HPLC instrument. The gradient protocol for the mobile phase, lasting for $50 \mathrm{~min}$, was arranged according to a method described earlier (Zapata, Rodriguez, and Garrido, 2000). The diode array detector enabled the recording of the full spectrum of each separated fraction between 200 and 800 $\mathrm{nm}$, and the recordings were saved for later data processing. Determination of pigment composition

Ten dominant fractions with clear spectra were chosen for 3D-multi-chromatogram analysis. The mathematical computation was performed using MATLAB R2015a software (MathWorks, Massachusetts, USA), adopting the trapezoidal rule to calculate the total peak area from every single wavelength with a resolution of $1 \mathrm{~nm}$ from 350 to 700 nm (Indrawati et al., 2012). The equation of Lichtenthaler (1987) was applied to estimate the total content of pheophytins in plant leaves in which the chlorophylls were completely converted into their derivatives.

\section{Polyphenol residue analysis}

The residues of two major polyphenols, epigallocatechin3-gallate (EGCG) and epigallocatechin (EGC), were detected and quantified using an in-house validated HPLC method by PT Angler Biochemlab (Surabaya, Indonesia). 
Table 2 Peak identification of remnant photosynthetic pigments extracted from the dregs of green and black teas, separated on a C8 HPLC column, and their typical spectra (in the eluent) following diode array detection.

\begin{tabular}{|c|c|c|c|c|c|c|c|c|c|c|c|c|}
\hline \multirow{2}{*}{$\begin{array}{c}\text { Peak } \\
\text { Number }\end{array}$} & \multirow{2}{*}{ Pigment } & \multicolumn{11}{|c|}{ Maximum (nm) } \\
\hline & & tR (min) & \multicolumn{5}{|c|}{ Observed } & \multicolumn{5}{|c|}{ Reported } \\
\hline 1 & pheophorbide $a$ & 15.8 & 409 & 508 & 538 & 609 & 665 & 409 & - & - & - & 665 \\
\hline 2 & lutein & 28.4 & $(424)$ & - & 447 & & 475 & $(422)$ & - & 446 & - & 474 \\
\hline 3 & chlorophyll $b$ & 33.5 & 462 & - & & 598 & 647 & 461 & - & 533 & 599 & 647 \\
\hline 4 & pheophytin $b$ sp. & 34.5 & 434 & - & 524 & 598 & 652 & 436 & - & - & - & 654 \\
\hline 5 & pheophytin $b$ & 34.9 & 434 & - & 527 & 598 & 652 & 436 & - & - & - & 654 \\
\hline 6 & pheophytin $a \mathrm{sp}$. & 36.0 & 409 & 503 & 533 & 609 & 664 & 409 & 505 & 535 & 608 & 665 \\
\hline 7 & pheophytin $a$ & 36.6 & 409 & 506 & 536 & 610 & 665 & 408 & 505 & 535 & 608 & 665 \\
\hline 8 & pheophytin $a^{\prime}$ & 36.8 & 409 & 506 & 538 & 610 & 666 & 408 & 505 & 535 & 609 & 666 \\
\hline 9 & $\beta$-carotene & 37.2 & $(425)$ & - & 454 & - & 476 & - & - & 452 & - & 474 \\
\hline 10 & pyropheophytin $a$ & 37.8 & 409 & 508 & 538 & - & 665 & 411 & 505 & 534 & 609 & 667 \\
\hline
\end{tabular}

Note: Data in parentheses denote the shoulder. * The data were reported by Suzuki and Shioi (2003) the same eluent as used in the present study.

\section{Description of the Experiment}

Sample preparation: The concentration of the pigment standard (positive control) was adjusted to $100 \mu \mathrm{g} \cdot \mathrm{mL}^{-1}$ according to the Lambert-Beer equation, with specific extinction coefficients $53.37 \mathrm{~L} . \mathrm{g}^{-1} . \mathrm{cm}^{-1}$ (at $667 \mathrm{~nm}$ in acetone) and $62.00 \mathrm{~L} \cdot \mathrm{g}^{-1} \cdot \mathrm{cm}^{-1}$ (at $643.3 \mathrm{~nm}$ in diethyl ether) for pheophytin $a$ and chlorophyll $b$, respectively (Jeffrey, Mantoura, and Wright, 1997; Küpper, Spiller, and Küpper, 2000). The concentration of the pigments in the dregs (four samples) was equalized with the standard at the maximum absorption (667 nm). Moreover, the solvent was thoroughly evaporated and replaced with an aqueous solution $(1 \% \mathrm{w} / \mathrm{v}$ Tween- 80$)$ with the aid of sonication. The sterile aqueous surfactant solution was employed as a negative control.

Briefly, from an inoculum of bacteria at $10^{8} \mathrm{CFU}_{\mathrm{mL}}^{-1}$ in nutrient broth medium, a volume of $50 \mu \mathrm{L}$ was pipetted and added into a $950 \mu \mathrm{L}$ solution of photosensitizers in an Eppendorf. The suspension was divided into two identical volumes and transferred into the wells of two microplates. One microplate was used for illumination treatment, and the second was covered with aluminum foil for dark treatment. A red LED lamp was set $16 \mathrm{~cm}$ above the orbital shaker to give $300 \pm 15 \mu \mathrm{mol} . \mathrm{m}^{-2} . \mathrm{s}^{-1}$ photons and the microplates with samples were gently agitated $(100 \mathrm{rpm})$ for $30 \mathrm{~min}$. Thereafter, each sample was supplemented with MuellerHinton broth, diluted, and plated in trypticase soy agar for the enumeration of the total number of viable cells. The percentage of dead cells was calculated based on the difference in the total number of survivors between the dark and illumination treatments.

Number of samples analyzed: The number of samples analyzed in the experiment were 84 samples. There were seven couple treatments (dark and illuminated) for each of the two indicator bacteria, which are one negative control, two positive controls using purified chlorophyll $b$ and pheophytin $a$, and pigments extracts from the dregs of four tea brands.

Number of repeated analyses: Individual analysis of all samples were repeated in duplicate.

Number of experiment replication: The data for each treatment were taken from three replication.

\section{Statistical Analysis}

The experimental data were analyzed with one-way nested ANOVA using Minitab software (Minitab LLC, Pennsylvania, USA) version 17.00 for Windows. The null hypothesis is rejected when the $p$-value is less than 0.05 . Furthermore, the comparison and grouping information were given based on Fisher's least significant difference (LSD) method at a 95\% confidence level.

\section{RESULTS AND DISCUSSION}

\section{Identification of pigments}

The pigments extracted from the dregs of six commercial teas were separated by HPLC with a diode array detector to record the absorption intensity in the ultra-violet to the visible region. The photosynthetic pigments, chlorophylls, and carotenoids are mainly responsible for harvesting light energy across the visible solar spectrum (Son et al., 2019).

Hence, they are characterized by distinctive absorption spectra in the visible region, which can be used as a reference in identification (Suzuki, Kamimura, and Hooker, 2015). Likewise, any molecular conversion or degradation of pigments can cause a spectral shift (Chen, 2014; Seifert, Pflanz, and Zude, 2014).

In this study, 13 signals were detected in the chromatograms belonging to the group of chlorophylls and carotenoids. Of these, 8 were identified as chlorophylls and 2 as carotenoids based on the reference standard, spectroscopic data, and retention times of pigments in tea leaves (Suzuki and Shioi, 2003; Zapata, Rodriguez, and Garrido, 2000). Figure 1 depicts the chromatograms and absorption patterns of the pigment fractions in the dregs of six commercial green and black teas. Along with it, Table 2 gives the list of fractions in comparison with the reference. The observed pigments, in descending order of polarity, were pheophorbide $a$, lutein, chlorophyll $b$, pheophytins $b$, pheophytins $a, \beta$-carotene, and pyropheophytin $a$. No signal was confirmed as belonging to chlorophyll $a$ in all the samples. Some polyphenol residues were detected in the early minutes of separation (1.6 and $7.2 \mathrm{~min}$ ) at $280 \mathrm{~nm}$, but their presence will be discussed in the next section.

In the photosynthetic apparatus of higher plants, the primary light-harvesting pigments are chlorophyll $a$ and $b$, while the accessory pigments are carotenoids (Croft and Chen, 2017). 


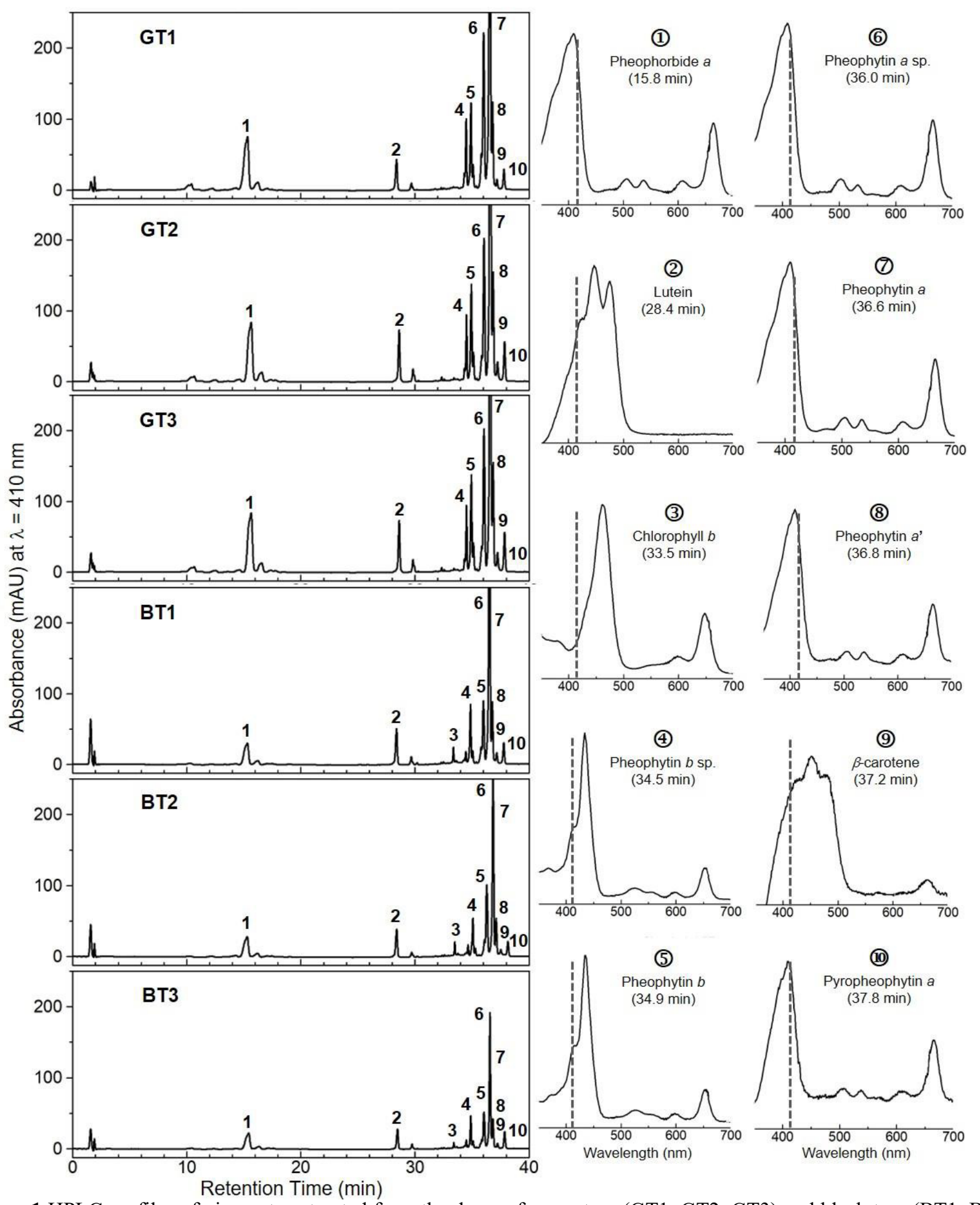

Figure 1 HPLC profiles of pigments extracted from the dregs of green teas (GT1, GT2, GT3) and black teas (BT1, BT2, BT3), monitored at $410 \mathrm{~nm}$. The visible absorbance spectrum of each pigment in the eluent solution is depicted on the righthand side, and the identification is listed in Table 1.

Pheophytin is a magnesium-free derivative of chlorophyll, which can be further converted into pheophorbide after detachment of the phytol tail.

These catabolites of chlorophyll are often formed by enzymatic processes during leaf senescence (Zepka, Jacob-Lopes, and Roca, 2019). Besides, these derivatives can be produced by heat and acid treatment during food processing (Amaya, 2016). Strong heat treatment may lead to the decarbomethoxylation of pheophytin, which yields pyropheophytin (Pareek et al., 2017). Heat treatment and the liberation of organic acid from tea leaves are inevitable during the manufacture of green and black teas, so many chlorophyll derivatives can be found in processed tea.

The absence of chlorophyll $a$ in all the samples and the intense pheophytins $a$ signal confirmed the total derivatization of chlorophyll $a$ in both green and black teas. Interestingly, the apparent signal of chlorophyll $b$ (peak number 3) was found only in black teas. This difference might be influenced by the different ways of processing tea leaves. The major steps in the manufacturing of green tea 
are heating (steaming or roasting), rolling, and drying, whereas those of black tea comprise withering, rolling, oxidation, and drying (Deb and Pou, 2016). The early steaming in green tea processing is presumed to hasten the thermal degradation of both chlorophylls $a$ and $b$, whereas the withering in black tea processing leads to a gentler biochemical conversion of chlorophylls. According to the catabolism pathway of chlorophylls, chlorophyll $b$ can first be converted into chlorophyll $a$ before further derivatization (Sato et al. 2018). Meanwhile, the degradation rate of chlorophyll $a$ is 2.5 times higher than that of chlorophyll $b$ (Koca, Karadeniz, and Burdurlu, 2006). The presence of chlorophyll $b$ residue is more likely than the presence of chlorophyll $a$ residue. This finding is in line with a study by Wijaya et al. (2010), who compared the presence of chlorophyll $b$ in fresh tea leaves, green teas, and black teas.

From the collation of the elution data, pheophytin $b$ existed in two species whose absorption spectra and peak intensities were almost alike, while pheophytin $a$ noticeably predominated over its another species and its epimer. Fu et al. (2012) and Hong et al. (2020) have reported the mass spectra of pheophytin species and epimer, in which the more polar species could be differentiated from pheophytin by the loss of two hydrogen molecules (divinyl pheophytin) or the addition of an oxygen molecule (hydroxy pheophytin). On the other hand, the epimerization of pheophytin $a$ into pheophytin $a^{\prime}$ as well as its conversion into a pyro-form derivative (removal of the $-\mathrm{CO}_{2} \mathrm{CH}_{3}$ moiety) is known to reduce its polarity (Lefebvre et al., 2020).

\section{Pigment composition}

As shown in Figure 1, each pigment exhibits a particular absorption pattern, so the selection of the monitoring channel greatly influences the peak intensity that appears in the chromatogram. The $430 \mathrm{~nm}$ channel is conventionally used in single detection for both chlorophylls and carotenoids because it gives a peak-rich chromatogram (Suzuki and Shioi, 2003). Some studies applied different channels to optimize the detection: $410 \mathrm{~nm}$ for pheophytin $a$ and certain carotenes, $430 \mathrm{~nm}$ for chlorophyll $a$ and pheophytin $b$, and $450 \mathrm{~nm}$ for chlorophyll $b$ and most carotenoids (Stinco et al., 2019; Wojdyło et al., 2021). Alternatively, the 3D-multi-chromatogram approach, which adds up every single peak intensity at a 1-nm resolution over a specified range of wavelengths, has recently been applied to overcome the need for detection at multiple channels. This method offers higher accuracy and a practical assessment of pigment abundance in extract mixtures without the quantification of individual fractions (Indrawati et al., 2012; Brotosudarmo et al., 2018; Indrawati et al. 2019).

Here, the composition of pigments in the dregs of tea samples was elucidated to determine the differences among tea types and to evaluate their antibacterial activity through light induction. Figure 2 shows the composition of the remnant pigments extracted from the dregs of green and black teas after hot water infusion at $90{ }^{\circ} \mathrm{C}$ for 5 and $20 \mathrm{~min}$. The percentage of abundance was calculated relative to the total pigment fractions found in the dregs.

The dominant fraction in all the samples was pheophytin $a$, ranging from $34 \%$ to $41 \%$, as the main derivative from chlorophyll $a$. In the group of chlorophylls, the order of abundance of the remnant pigments recovered from the dregs of green teas was as follows: pheophytin $a>$ pheophytin $a$ sp. $>$ pheophytin $b>$ pheophytin $b \mathrm{sp} .>$ pheophytin $a^{\prime}>$ pheophorbide $a>$ pyropheophytin $a>$ chlorophyll $b$. This order is slightly different for the remnant pigments recovered from the dregs of black teas, in which either chlorophyll $b$ or pheophytin $b$ was always found as the second most abundant pigment. This is in line with our previous statement that the different processing of green and black teas affects mainly the remaining chlorophyll $b$. Generally, since the chlorophyll $a / b$ ratios in vegetation are usually around $2.5-4.0$ (Croft and Chen, 2017), the total abundance of the derivatives from chlorophyll $a$ should normally be higher than that of chlorophyll $b$.

In the group of carotenoids, the percentage of lutein found in the dregs varied among the tea samples, while that of $\beta$ carotene was comparable. The presence of lutein and $\beta$ carotene has been known to be important in tea grading as the precursors of aroma (Zhou, Li, and He, 2017). These two major carotenoids are usually found at a ratio of 5:3 of lutein to $\beta$-carotene in fresh tea leaves (Zhang et al., 2020), but according to the findings in the present study, this ratio might be higher after tea processing, particularly in black tea samples.

Table 3 provides the quantification of the total amount of pheophytins recovered from the dregs of green and black teas. The order of abundance of the pigments was as follows: GT1 > GT2 > GT3 > BT1 > BT2 > BT3. The pigments extracted from the dregs of green teas were nearly twice as abundant as those of black teas. The longer processing steps in the black tea manufacture presumably cause more degradation of leaf pigments. The fermentation and drying procedures are indeed aimed at reducing the chlorophyll content, which can cause black teas to have a grassy aroma and inferior quality (Pou, Paul, and Malakar, 2019).

When the infusion time was increased from 5 to $20 \mathrm{~min}$, the total amount of remnant pheophytins was reduced by about $10 \%$. This reduction could be influenced by the further extraction of tea saponins, which are weak surfactants; hence it can facilitate the dissolution of some photosynthetic pigments (Suzuki and Shioi, 2003; Safdar et al., 2016).

Table 3 Total amount of pheophytins found in the dregs of green and black teas after hot water infusion at $90{ }^{\circ} \mathrm{C}$ for 5 and $20 \mathrm{~min}$.

\begin{tabular}{ccccccc}
\hline Infusion & \multicolumn{5}{c}{ Total Amount of Pheophytins in the Dregs (mg $\mathbf{~ g}^{-\mathbf{1}}$ of Dry Basis) } \\
\cline { 2 - 7 } Time & GT1 & GT2 & GT3 & BT1 & BT2 & BT3 \\
\hline 5 min & $3.23 \pm 0.12$ & $3.08 \pm 0.07$ & $2.84 \pm 0.06$ & $1.50 \pm 0.04$ & $1.15 \pm 0.01$ & $0.76 \pm 0.00$ \\
$20 \mathrm{~min}$ & $2.90 \pm 0.04$ & $2.76 \pm 0.14$ & $2.14 \pm 0.02$ & $1.24 \pm 0.25$ & $1.07 \pm 0.02$ & $0.69 \pm 0.00$ \\
\hline
\end{tabular}

Note: Values are expressed as means $\pm S D$. 

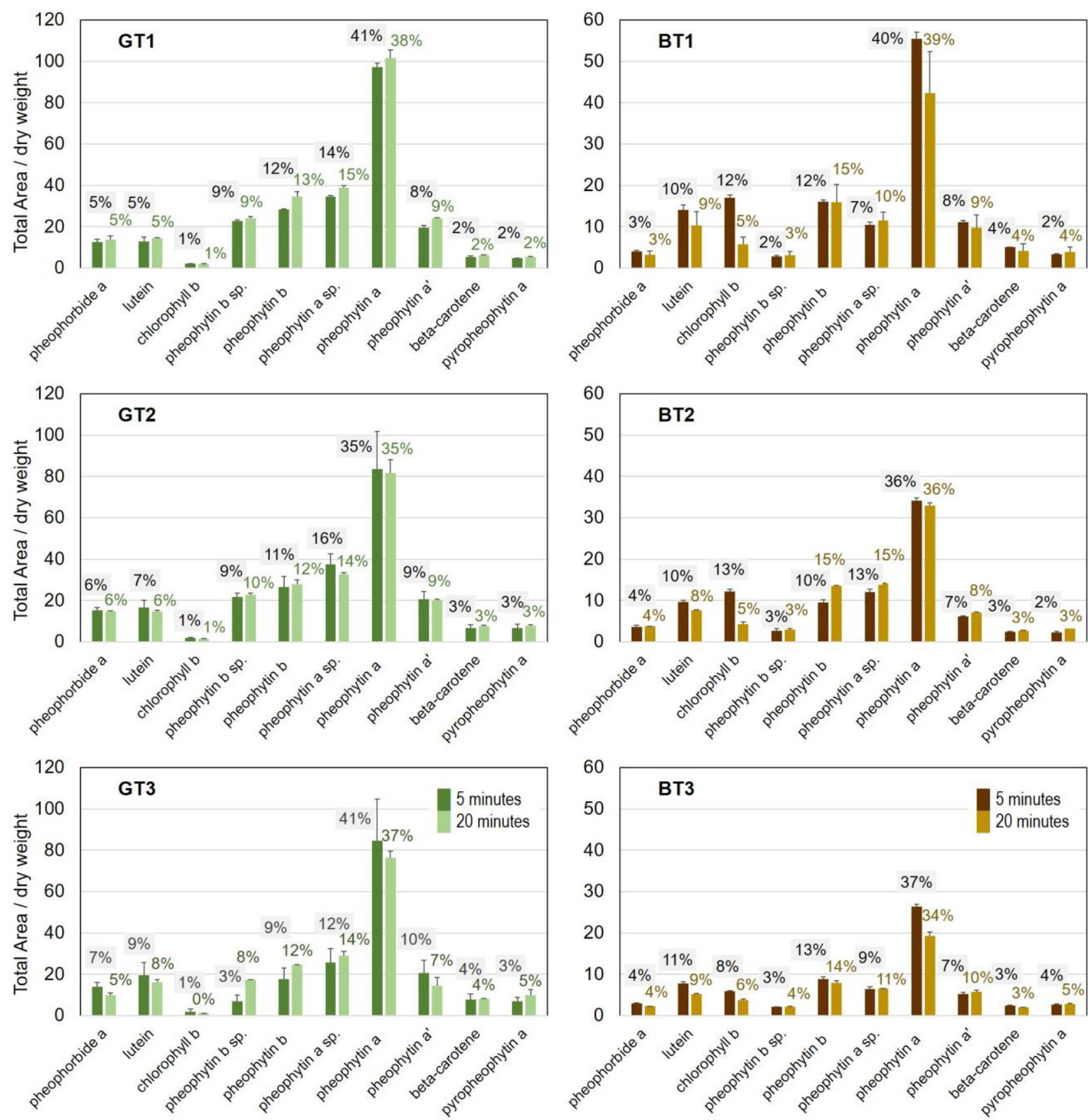

Figure 2 Composition of the remnant pigments extracted from the dregs of green teas (GT1, GT2, GT3) and black teas (BT1, BT2, BT3) after hot water infusion at $90^{\circ} \mathrm{C}$ for 5 and $20 \mathrm{~min}$. For each fraction, the total area was calculated based on a multi-chromatogram approach, summing up consecutive peak areas from 350 to $700 \mathrm{~nm}$. Values are expressed as means $\pm S D$ of duplicate analyses. The data label denotes the abundance of each fraction in the extract.

Table 4 Residues of polyphenols jointly extracted with the remnant pigments from the dregs of green and black teas, after hot water infusion at $90{ }^{\circ} \mathrm{C}$ for $5 \mathrm{~min}$.

\begin{tabular}{ccccc}
\hline \multirow{2}{*}{ Fraction } & \multicolumn{4}{c}{ Polyphenol Residue in the Dregs (mg.g $\mathbf{~ o f ~ W e t ~ B a s i s ) ~}^{-1}$} \\
\cline { 2 - 5 } & GT1 & GT2 & BT1 & BT2 \\
\hline EGCG & $4.25 \pm 0.66$ & $3.26 \pm 0.03$ & $0.45 \pm 0.02$ & $0.126 \pm 0.01$ \\
EGC & $0.55 \pm 0.03$ & $0.76 \pm 0.08$ & not detected & not detected \\
\hline
\end{tabular}

Note: Values are expressed as means $\pm S D$. EGCG - epigallocatechin-3-gallate; EGC - epigallocatechin.

In addition, advanced degradation of chlorophylls into small colorless compounds possibly takes place during prolonged thermal treatment (Samide and Tutunaru, 2017).
Despite such a reduction in the total amount of pheophytins (Table 3), no extreme change in the distribution of pigment fractions was observed, as can be seen in Figure 2. Some alterations in the percentage of 
pigment fractions from 5 to $20 \mathrm{~min}$ tea brewing were probably the result of intraspecies conversion or epimerization in the group of pheophytins $a$ and $b$.

Likewise, further derivatization of chlorophyll $b$ in samples of black teas compensated the increase in the percentage of pheophytin $b$.

From these results, two samples with the highest content of pheophytins were chosen among each group of green and black teas (i.e., GT1, GT2, BT1, and BT2) for the antibacterial assay. The dregs extract was used as a mixture of pigments with a determined composition. As mentioned before, some residual polyphenols were jointly extracted with the pigments and detected in the UV region $(280 \mathrm{~nm})$ of the chromatogram. Table 4 provides the quantification of the polyphenol residues in the dregs extracts.

\section{Antibacterial photosensitization}

The principle of antibacterial photosensitization also referred to as photodynamic inactivation, is based on interactions among light, a photosensitizer, and oxygen, which produce radical oxygen species that are highly cytotoxic (Cieplik et al., 2018). This method has been intensively explored not only in medicine but also in the fields of fisheries, pest control, and food disinfection (Alves et al., 2015). The light source can be an incandescentlamp, a laser, or a LED that emits light in the same wavelength range as the absorption spectrum of the photosensitizer. Moreover, the photosensitizer itself must be non-toxic, and a naturally occurring compound is preferred when it isused in food products (Ghate, Zhou, and Yuk, 2019).

In the present study, the dregs extracts were applied to bacterial cultures and parallelly incubated under dark and illumination conditions. Purified pheophytin $a$ and chlorophyll $b$ were used as positive controls, representing the most dominant fractions in the remnant pigments from the dregs as well as in the residual pigments from tea leaves. The dispersing medium, an aqueous solution of $1 \%(\mathrm{w} / \mathrm{v})$ Tween-80, was used as a negative control to verify the light effect against bacteria in the absence of a photosensitizer. The numbers of living cells after $30 \mathrm{~min}$ treatments are provided in Figure 3.

After incubation under dark conditions, there was no reduction in the total number of viable cells of $S$. aureus and

$E$. coli in the negative and positive controls and the treatments using dregs extracts. This result revealed that in the dark, the pigments at a concentration of $100 \mu \mathrm{g} \mathrm{mL}^{-1}$ had no toxic effect against the pathogen.

The red LED, emitting at $640 \pm 60 \mathrm{~nm}$, was applied in the illumination treatment to stimulate the photosensitization of pheophytins and chlorophyll $b$, which also have an absorption spectrum in the red region. The exposure to red light was expected to have a low antibacterial effect. The longer wavelength of visible light has lower energy and hence little impact on bacterial growth (Ghate et al., 2013; Prasad et al., 2020).

Figure 3 shows the apparent reduction in the number of living cells when the photosensitizer was applied to the bacterial suspension, both with the positive controls and with the dregs extracts. The occurrence of antibacterial photosensitization was confirmed by nested ANOVA analysis, which gave a $p$-value $<0.05$ for the illumination treatment. In other words, the first hypothesis was accepted, stating that illumination causes a significant effect on the number of viable bacteria treated with dregs extract. The differences in the number of survivors between dark and illumination treatments were $0.16-0.87 \log$ and $0.22-0.35$ $\log$ for $S$. aureus and E. coli, respectively. The greatest effect was found in the dregs extract of GT2, which caused a reduction of nearly one log cycle in the $S$. aureus culture. Furthermore, the magnitude of photodynamic inactivation was calculated as the percentage of dead cells in illumination treatments, in which the dark treatment was assumed to have zero death (Table 5). The percentage of dead cells in the negative control groups was below $5 \%$, whereas that in the positive controls and the treatments with dregs extract was higher. The small photo-killing effect observed in the negative control group was probably due to antibacterial photosensitization by an endogenous photosensitizer in the bacterial cells.

Several metabolites inside bacterial cells, such as protoporphyrin IX, coproporphyrin III, and uroporphyrin, have been recognized as visible-light sensitive compounds (Hoenes et al., 2020; Fyrestam et al., 2015).

The presence of an exogenous photosensitizer caused significantly greater inactivation of bacterial cultures, as confirmed by Fisher's LSD test against the negative control group. Nevertheless, the magnitude of photosensitization among the four tea types was comparable in both bacteria, with the same alphabetical notation and acceptance of the null hypothesis. Despite the antimicrobial photosensitization of GT2 being somewhat higher than that of the other samples, the small difference in pigment composition between the dregs extracts of green and black teas might not greatly affect their inactivation capacity. In this experiment, the concentration of the dregs extracts has been calibrated so that they have a light absorption intensity equal to that of pheophytin $a$ at $100 \mu \mathrm{g} \mathrm{mL}^{-1}$. However, the percentage of dead cells in the treatments of

S. aureus with dregs extract was markedly higher than that in the positive controls. A similar difference was found in the experiments with $E$. coli, although it was not statistically significant. This finding was presumably caused by the synergistic effect of several chlorophyll derivatives in the dregs extract. Acedo et al. (2014) reported the beneficial effect of using a combination of photosensitizers to increase the efficacy of photosensitization. In addition, another possible ancillary effect came from the presence of residual EGCG, which enhanced the cytotoxic effect of photosensitization (Raish et al., 2010; Senapathy, George, and Abrahamse, 2020). This ancillary effect could be investigated in further studies.

In general, the attractiveness of antimicrobial photosensitization in modern research arises from its potency in rapid non-thermal disinfection using non-UV light (Purushothaman and Mol, 2021). Investigations into novel photosensitizers are ongoing to increase the efficacy of photosensitization, along with the determination of the optimum photosensitizer concentration, irradiation dose, and incubation time (Amaral, Azevedo, and Perussi, 2018). Although photodynamic treatment is capable of killing a broad spectrum of pathogenic bacteria, the sensitivity varies depending on the membrane characteristics of the bacteria. The Gram-positive bacteria are often more susceptible to photosensitization because of their single-cell wall with high porosity. 

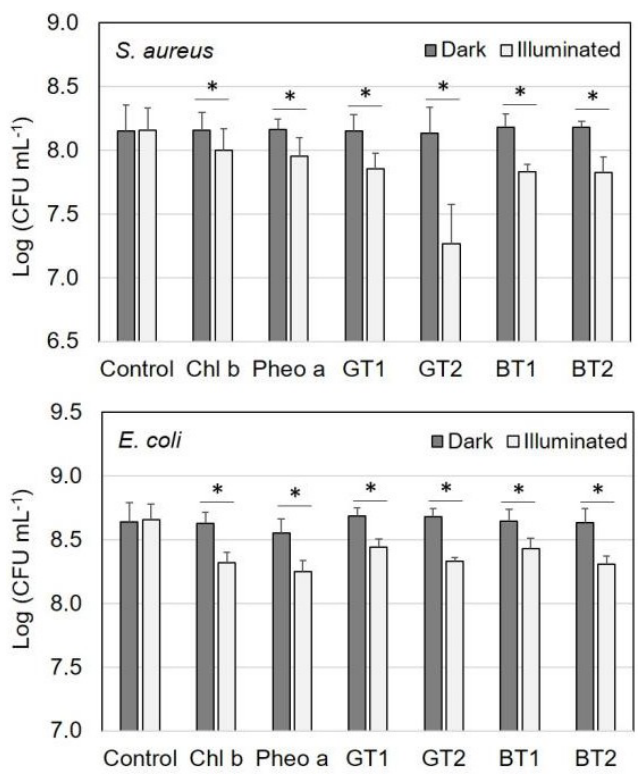

Figure 3 Total number of viable cells after 30-min incubation with $1 \% \mathrm{w} / \mathrm{v}$ Tween-80 (Control), chlorophyll $b$ $(\mathrm{Chl} b$ ), and pheophytin $a$ (Pheo $a$ ), as well as the pigments extracted from the dregs of green teas (GT1, GT2) and black teas (BT1, BT2), in the dark and illuminated by a red, LED light. The error bar shows the standard error of the mean $(n=3)$. The star indicates a significant difference $(p<0.05)$ between treatments. based on nested ANOVA analysis.

Table 5 Percentage of dead cells after 30-min incubation with pigments extracted from dregs of green and black teas under red LED illumination.

\begin{tabular}{ccc}
\hline \multirow{2}{*}{ Treatment } & \multicolumn{2}{c}{ Dead Cells (\%) } \\
\cline { 2 - 3 } & \multicolumn{1}{c}{ S. aureus } & E. coli \\
\hline Control & $4.9 \pm 2.6^{\mathrm{d}}$ & $3.9 \pm 1.3^{\mathrm{b}}$ \\
Chlorophyll $b$ & $31.0 \pm 9.8^{\mathrm{c}}$ & $27.6 \pm 9.7^{\mathrm{a}}$ \\
Pheophytin $a$ & $38.9 \pm 7.2^{\mathrm{bc}}$ & $29.3 \pm 7.2^{\mathrm{a}}$ \\
GT1 & $49.5 \pm 6.1^{\mathrm{abc}}$ & $42.8 \pm 2.0^{\mathrm{a}}$ \\
GT2 & $67.4 \pm 4.5^{\mathrm{a}}$ & $40.5 \pm 3.4^{\mathrm{a}}$ \\
BT1 & $51.2 \pm 1.6^{\mathrm{abc}}$ & $39.2 \pm 2.3^{\mathrm{a}}$ \\
BT2 & $55.2 \pm 9.2^{\mathrm{ab}}$ & $34.3 \pm 6.6^{\mathrm{a}}$ \\
\hline
\end{tabular}

Note: Values are expressed as means \pm SEM of three repetitions. Different letters indicate statistically significant differences between groups of treatments with the same targeted bacteria $(p<0.05)$.

The complexity of the cell wall in Gram-negative bacteria might hamper the attachment and absorption of photosensitizers (Mesquita et al., 2018). Our findings are in line with this, as $S$. aureus (Gram-positive) exhibited a higher susceptibility than E. coli (Gram-negative) to antimicrobial photosensitization.

\section{CONCLUSION}

In conclusion, the presence of eight chlorophylls and two carotenoids has been identified in the dregs extracts from six commercial green and black teas. The total amount of remnant pigments in the dregs of green teas was generally higher than that of black teas. The pigment distribution in both tea types was comparable, except for the presence of residual chlorophyll $b$ in black teas. The most dominant pigment in all the samples was pheophytin $a$, followed by other species of pheophytins $a$ and $b$, the epimer of pheophytin $a$, and pyropheophytin. The dregs extract had a significant effect on the antimicrobial photosensitization against $S$. aureus and $E$. coli. The magnitude of the killing effect was comparable among the tea types and could even be higher than that of a single purified pigment. In the utilization of pigments from dregs, the suggested selection ought to be pointed to the amount of total remnant pigments rather than tea types.

\section{REFERENCES}

Acedo, P., Stockert, J. C., Cañete, M., Villanueva, A. 2014. Two combined photosensitizers: A goal for more effective photodynamic therapy of cancer. Cell Death and Disease, vol. 5, no. 3, p. 1-12. https://doi.org/10.1038/cddis.2014.77

Alves, E., Faustino, M. A. F., Neves, M. G. P. M. S., Cunha, A., Nadais, H., Almedia, A. 2015. Potential applications of porphytins in photodynamic inactivation beyond the medical scope. Journal of Photochemistry and Photobiology C: Photochemistry Reviews, vol. 22, p. 34-57. https://doi.org/10.1016/j.jphotochemrev.2014.09.003

Amaral, L. S., Azevedo, E. B., Perussi, J. R. 2018. The response surface methodology speeds up the search for optimal parameters in the photoinactivation of $E$. coli by photodynamic therapy. Photodiagnosis and Photodynamic Therapy, vol. 22, p. 26-33. https://doi.org/10.1016/j.pdpdt.2018.02.020

Amaya, D. B. R. 2016. Natural food pigments and colorants. Current Opinion in Food Science, vol. 7, p. 20-26. https://doi.org/10.1016/j.cofs.2015.08.004

Brotosudarmo, T. H. P., Heriyanto, Shioi, Y., Indriatmoko, Adhiwibawa, M. A. S., Indrawati, R., Limantara, L. 2018. Composition of the main dominant pigments from potential two edible seaweeds. Philippine Journal of Science, vol. 147, no. 1, p. 47-55.

Chaturvedula, V. S. P., Prakash, I. 2011. The aroma, taste, color and bioactive constituents of tea. Journal of Medicinal Plants Research, vol. 5, no. 11, p. 2110-2124. https://doi.org/10.5897/JMPR.9001187

Chen, M. 2014. Chlorophyll modifications and their spectral extension in oxygenic photosynthesis. Annual Review of Biochemistry, vol. 83, p. 26.1-26.24.

https://doi.org/10.1146/annurev-biochem-072711-162943

Chowdhury, A., Sarkar, S., Chowdhury, A., Bardhan, S., Mandal, P., Chowdhury, M. 2016. Tea waste management: A case study from West Bengal, India. Indian Journal of Science and Technology, vol. 9, no. 42, p. 1-6. https://doi.org/10.17485/ijst/2016/v9i42/89790

Cieplik, F., Deng, D., Crielaard, W., Buchalla, W., Hellwig, E., Al-Ahmad, A., Maisch, T. 2018. Antimicrobial photodynamic therapy - what we know and what we don't. Critical Reviews in Microbiology, vol. 44, no. 5, p. 571-589. https://doi.org/10.1080/1040841X.2018.1467876

Croft, H., Chen, J. M. 2017. Leaf pigment content. Reference Module in Earth Systems and Environmental Sciences. Oxford : Elsevier Inc., p. 1-26. https://doi.org/10.1016/B978-0-12409548-9.10547-0

Deb, S., Pou, K. R. J. 2016. A review of withering in the processing of black tea. Journal of Biosystems Engineering, vol. 41, no. 4, p. 365-372. https://doi.org/10.5307/JBE.2016.41.4.365

Diby, L., Kahia, J., Kouamé, C., Aynekulu, E. 2017. Tea, coffee, and cocoa. Encyclopedia of Applied Plant Sciences, $2^{\text {nd }}$ ed, vol. 3, p. 420-425. https://doi.org/10.1016/B978-0-12$\underline{394807-6.00179-9}$ 
Donlao, N., Ogawa, Y. 2019. The influence of processing conditions on catechin, caffeine and chlorophyll contents of green tea (Camelia sinensis) leaves and infusions. LWT-Food Science and Technology, vol. 116, p. 1-8. https://doi.org/10.1016/j.lwt.2019.108567

Dubey, K. K., Janve, M., Ray, A., Singhal, R. S. 2020. Ready-to-drink tea. Trends in Non-alcoholic Beverages, Oxford : Elsevier Inc., p. 101-140. https://doi.org/10.1016/B978-0-12-816938-4.00004-5

Fu, W., Magnúsdóttir, M., Brynjólfson, S., Palsson, B. O., Paglia, G. 2012. UPLC-UV-MS ${ }^{\mathrm{E}}$ analysis for quantification and identification of major carotenoid and chlorophyll species in algae. Analytical and Bioanalytical Chemistry, vol. 404, p. 3145-3154. https://doi.org/10.1007/s00216-012-6434-4

Fyrestam, J., Bjurshammar, N., Paulsson, E., Johannsen, A., Östman, C. 2015. Determination of porphyrins in oral bacteria by liquid chromatography electrospray ionization tandem mass spectrometry. Analytical and Bioanalytical Chemistry, vol. 407, no. 23, p. 7013-7023. https://doi.org/10.1007/s00216$\underline{015-8864-2}$

Gerola, A. P., Santana, A., França, P. B., Tsubone, T. M., Oliveira, H. P. M., Caetano, W., Kimura, E., Hioka, N. 2011. Effects of metal and the phytil chain on chlorophyll derivatives: Physicochemical evaluation for photodynamic inactivation of microorganisms. Photochemistry and Photobiology, vol. 87, p. 884-894. https://doi.org/10.1111/j.1751-1097.2011.00935.x

Ghate, V. S., Ng, K. S., Zhou, W., Yang, H., Khoo, G. H., Yoon, W. B., Yuk, H. G. 2013. Antibacterial effect of light emitting diodes of visible wavelengths on selected foodborne pathogens at different illumination temperatures. International Journal of Food Microbiology, vol. 166, p. 399-406. https://doi.org/10.1016/j.ijfoodmicro.2013.07.018

Ghate, V. S., Zhou, W., Yuk, H. G. 2019. Perspectives and trends in the application of photodynamic inactivation for microbiological food safety. Comprehensive Reviews in Food Science and Food Safety, vol. 18, p. 402-424. https://doi.org/10.1111/1541-4337.12418

Hoenes, K., Wenzel, U., Spellerberg, B., Hessling, M. 2020. Photoinactivation sensitivity of Staphylococcus carnosus to visible-light irradiation as a function of wavelength. Photochemistry and Photobiology, vol. 96, no. 1, p. 156-169. https://doi.org/10.1111/php.13168

Hong, J. E., Lim, J. H., Kim, T. Y., Jang, H. Y., Oh, H. B.,

Chung, B. G., Lee, S. Y. 2020. Photo-oxidative protection of chlorophyll $a$ in C-phycocyanin aqueous medium. Antioxidants, vol. 9, no. 1235, p. 1-13. https://doi.org/10.3390/antiox9121235

Hussain, S., Anjali, K. P., Hassan, S. T., Dwivedi, P. B. 2018. Waste tea as a novel adsorbent: a review. Applied Water Science, vol. 8, no. 165, p. 1-16.

https://doi.org/10.1007/s13201-018-0824-5

Indrawati, R., Ozols, M., Indriatmoko, Heriyanto, Brotosudarmo, T. H. P., Limantara, L. 2012. Re-evaluation on multi-chromatogram approach of 3D-chromatograpic-data. Journal of Biomaterial Chemistry, vol. 1, p. 12-16.

Indrawati, R., Heriyanto, Brotosudarmo, T. H. P., Limantara, L. 2019. Distribution of chlorophylls and carotenoids in the different parts of thallus structure from three Sargassum spp. as revealed by multi-chromatograms HPLC approach. In Proceedings of the Indonesian Chemical Society. Malang, Indonesia : Indonesian Chemical Society, p. 5-9. https://doi.org/10.34311/pics.2019.01.1.5

Indrawati, R., Lolita, A. M., Limantara, L. 2021. Terapi fotodinamik antimikroba: Prospek baru dalam penanganan pangan? (Antimicrobial photodynamic therapy: A new prospect in food handling?). Jurnal Sains dan Terapan Kimia, vol. 15, no. 1, p. 74-90. (In Indonesian) https://doi.org/10.20527/jstk.v15i1.8771

Jeffrey, S. W., Mantoura, R. F. C., Wright, S. W. 1997. Phytoplankton pigments in oceanography: Guidelines to modern methods. Paris, France : UNESCO Publishing, 661 p. ISBN 92-3-103275-5.

Kabir, M. M., Mouna, S. S. P., Akter, S., Khandaker, S., Didar-ul-Alam, Md., Bahadur, N. M., Mohinuzzaman, M., Islam, Md. A., Shenashen, M. A. 2021. Tea waste based natural adsorbent for toxic pollutant removal from waste samples. Journal of Molecular Liquids, vol. 322, p. 1-16. https://doi.org/10.1016/j.molliq.2020.115012

Koca, N., Karadeniz, F., Burdurlu, H. S. 2006. Effect of pH on chlorophyll degradation and colour loss in blanched green peas. Food Chemistry, vol. 100, p. 609-615. https://doi.org/10.1016/j.foodchem.2005.09.079

Küpper, H., Spiller, M., Küpper, F. C. 2000. Photometric method for the quantification of chlorophylls and their derivatives in complex mixtures: Fitting with Gauss- peak spectra. Analytical Biochemistry, vol. 286, no. 2, p. 247-256. https://doi.org/10.1006/abio.2000.4794

Kustov, A. V., Belykh, D. V., Smirnova, N. L., Venediktov,

E. A., Kudayarova, T. V., Kruchin, S. O., Khudyaeva, I. S., Berezin, D. B. 2018. Synthesis and investigation of watersoluble chlorophyll pigments for antimicrobial photodynamic therapy. Dyes and Pigments, vol. 149, p. 553-559. https://doi.org/10.1016/j.dyepig.2017.09.073

Lefebvre, T., Talbi, A., Atwi-Ghaddar, S., Destandau, E., Lesellier, E. 2020. Development of an analytical method for chlorophyll pihments separation by reversed-phase supercritical fluid chromatography. Journal of Chromatography A, vol. 1612, p. 1-8. https://doi.org/10.1016/j.chroma.2019.460643

Lichtenthaler, H. K. 1987. Chlorophylls and carotenoids: Pigments of photosynthetic biomembranes. Methods in Enzymology, vol. $\quad 148, \quad$ p. $350-382$. https://doi.org/10.1016/0076-6879(87)48036-1

Mesquita, M. Q., Dias, C. J., Neves, M. G. P. M. S., Almeida, A., Faustino, M. A. F. 2018. Revisiting current photoactive materials for antimicrobial photodynamic therapy. Molecules, vol. 23, no. $10, \quad$ p. $1-47$. https://doi.org/10.3390/molecules23102424

Oktavia, L., Mulyani, I., Suendo, V. 2021. Investigation of chlorophyll-a derived compounds as photosensitizer for photodynamic inactivation. Bulletin of Chemical Reaction Engineering and Catalysis, vol. 16, no. 1, p. 161-169. https://doi.org/10.9767/bcrec.16.1.10314.161-169

Pareek, S., Sagar, N. A., Sharma, S., Kumar, V., Agarwal, T., Gonzales-Aguilar, G. A., Yahia, E. M. 2017. Chlorophylls: Chemistry and biological functions. In Yahia, E. M. Fruit and vegetable phytochemicals: Chemistry and human health. $2^{\text {nd }}$ ed. Chichester, UK : John Wiley and Sons, Ltd., p. 269-284. ISBN 9781119158042 https://doi.org/10.1002/9781119158042.ch14

Pou, K. R. J., Paul, S. K., Malakar, S. 2019. Industrial processing of CTC black tea. In Grumezescu, A. M., Holban, A. M. Caffeinated and cocoa based beverages. Vol. 8. Duxford, UK : Woodhead Publishing, p. 131-162. ISBN 9780-12-815865-4.

Prasad, A., Du, L., Zubair, M., Subedi, S., Ullah, A., Roopesh, M. S. 2020. Applications of light-emitting diodes (LEDs) in food processing and water treatment. Food Engineering Reviews, vol. 12, p. 268-289. https://doi.org/10.1007/s12393-020-09221-4 
Purushothaman, T., Mol, K. I. 2021. A critical review on antimicrobial photodynamic inactivation using light emitting diode (LED). International Journal of Arts, Science and Humanities, vol. 8, no. 3, p. 124-130. https://doi.org/10.34293/sijash.v8i3.3476

Raish, M., Husain, S. Z. A., Bae, S. M., Han, S. J., Park, C. H., Shin, J. C. 2010. Photodynamic therapy in combination with green tea polyphenol EGCG enhances antitumor efficacy in human papillomavirus 16 (E6/E7) immortalized tumor cells. Journal of Applied Research, vol. 10, no. 2, p. 58-67.

Rodrigues, V. C., Silva, M. V., Santos, A. R., Zielinski, A.

A. F., Haminiuk, C. W. I. 2015. Evaluation of hot and cold extraction of bioactive compounds in teas. International Journal of Food Science and Technology, vol. 50, p. 20382045. https://doi.org/10.1111/ijfs. 12858

Roshanak, S., Rahimmalek, M., Goli, S. A. H. 2016. Evaluation of seven different drying treatments in respect to total flavonoid, phenolic, vitamin $\mathrm{C}$ content, chlorophyll, antioxidant activity and color of green tea (Camellia sinensis or C. assamica) leaves. Journal of Food Science and Technology, vol. 53, no. 1, p. 721-729. https://doi.org/10.1007/s13197-015-2030-x

Safdar, N., Sarfaraz, A., Kazmi, Z., Yasmin, A. 2016. Ten different brewing methods of green tea: comparative antioxidant study. Journal of Applied Biology and Biotechnology, vol. 4, no. 3, p. 33-40. https://doi.org/10.7324/JABB.2016.40306

Samide, A., Tutunaru, B. 2017. Thermal behavior of the chlorophyll extract from a mixture of plants and seaweed. Journal of Thermal Analysis and Calorimetry, vol. 127, p. 597604. https://doi.org/10.1007/s10973-016-5490-y

Sato, T., Shimoda, Y., Matsuda, K., Tanaka, A., Ito, H. 2018. Mg-dechelation of chlorophyll $a$ by Stay-Green activates chlorophyll $b$ degradation through expressing Non-Yellow Coloring 1 in Arabidopsis thaliana. Journal of Plant Physiology, vol. 222, p. 94-102.

https://doi.org/10.1016/j.jplph.2018.01.010

Seifert, B., Pflanz, M., Zude, M. 2014. Spectral shift as advanced index for fruit chlorophyll breakdown. Food and Bioprocess Technology, vol. 7, p. 2050-2059. https://doi.org/10.1007/s11947-013-1218-1

Senapathy, G. J., George, B. P., Abrahamse, H. 2020. Enhancement of phthalocyanine mediated photodynamic therapy by catechin on lung cancer cells. Molecules, vol. 25, p. 1-13. https://doi.org/10.3390/molecules25214874

Son, M., Pinnola, A., Bassi, R., Schlau-Cohen, G. S. 2019. The electronic structure of Lutein 2 is optimized for light harvesting in plants. Chem., vol. 5, no. 3, p. 575-584. https://doi.org/10.1016/j.chempr.2018.12.016

Stinco, C. M., Benítez-González, A. M., Meléndez-Martínez, A. J., Hernanz, D., Vicario, I. M. 2019. Simultaneous determination of dietary isoprenoids (carotenoids, chlorophylls and tocopherols) in human faeces by Rapid Resolution Liquid Chromatography. Journal of Chromatography A, vol. 1583, p. 63-72. https://doi.org/10.1016/j.chroma.2018.11.010

Suzuki, Y., Shioi, Y. 2003. Identification of chlorophylls and carotenoids in major teas by high-performance liquid chromatography with photodiode array detection. Journal of Agricultural and Food Chemistry, vol. 51, p. 5307-5314. https://doi.org/10.1021/jf030158d

Suzuki, K., Kamimura, A., Hooker, S. B. 2015. Rapid and highly sensitive analysis of chlorophylls and carotenoids from marine phytoplankton using ultra-high performance liquid chromatography (UHPLC) with the first derivative spectrum chromatogram (FDSC) technique. Marine Chemistry, vol. 176, p. 96-109. https://doi.org/10.1016/j.marchem.2015.07.010
Wei, Y., Fang, S., Jin, G., Ni, T., Hou, Z., Li, T., Deng, W. W., Ning, J. 2020. Effects of two yellowing process on colour, taste, and nonvolatile compounds of bud yellow tea. International Journal of Food Science and Technology, vol. 55, no. 8, p. 2931-2941. https://doi.org/10.1111/IJFS.14554

Wei, Y., Li, T., Xu, S., Ni, T., Deng, W. W., Ning, J. 2021.

The profile of dynamic changes in yellow tea quality and chemical composition during yellowing process. $L W T-$ Food Science and Technology, vol. 139, p. 1-11. https://doi.org/10.1016/j.lwt.2020.110792

Wijaya, W., Heriyanto, Prasetyo, B., Limantara, L. 2010. Determination of chlorophylls and carotenoids content in three major teas based on peak area from HPLC chromatogram. In $38^{\text {th }}$ Meeting of National Working Group on Indonesian Medicinal Plant and German Academic Exchange Service : Proceeding of International Conference on Medicinal Plants. Surabaya, Indonesia : Widya Mandala Catholic University, p. 103-111. ISBN 978-602-96839-1-2.

Wojdyło, A., Nowicka, P., Tkacz, K., Turkiewicz, I. P. 2021. Fruit tree leaves as unconventional and valuable source of chlorophyll and carotenoid compounds determined by liquid chromatography-photodiode-quadrupole/time of flightelectrospray ionization-mass spectrometry (LC-PDA-qTofESI-MS). Food Chemistry, vol. 349, p. 1-12. https://doi.org/10.1016/j.foodchem.2021.129156

Yu, X., Hu, S., He, C., Zhou, J., Qu, F., Ai, Z., Chen, Y., Ni, D. 2019. Chlorophyll metabolism in postharvest tea (Camellia sinensis L.) leaves: variations in color values, chlorophyll derivatives, and gene expression levels under different withering treatments. Journal of Agricultural and Food Chemistry, vol. 67, p. 10624-10636. https://doi.org/10.1021/acs.jafc.9b03477

Zapata, M., Rodriguez, F., Garrido, J. L. 2000. Separation of chlorophylls and carotenoids from marine phytoplankton: a new HPLC method using a reversed phase $\mathrm{C}_{8}$ column and pyridine-containing mobile phases. Marine Ecology Progress Series, vol. 195, p.29-45. https://doi.org/10.3354/meps195029

Zepka, L. Q., Jacob-Lopes, E., Roca, M. 2019. Catabolism and bioactive properties of chlorophylls. Current Opinion in Food Science, vol. 26, p. 94-100. https://doi.org/10.1016/j.cofs.2019.04.004

Zhang, G., Yang, J., Hu, C., Zhang, X., Li, X., Gao, S., Ouyang, X., Ma, N., Wei, H. 2019. Green synthesis of Chlorin e6 and tests of its photosensitive bactericidal activities. Journal of Forestry Research, vol. 30, p. 2349-2356. https://doi.org/10.1007/s11676-018-0756-9

Zhang, Y., Gao, W., Cui, C., Zhang, Z., He, L., Zheng, J., Hou, R. 2020. Development of a method to evaluate the tenderness of fresh tea leaves based on rapid, in-situ Raman spectroscopy scanning for carotenoids. Food Chemistry, vol. 308, p. 1-8. https://doi.org/10.1016/j.foodchem.2019.125648

Zhou, R., Li, X., He, Y. 2017. Grading of green tea and quantitative determination of beta-carotene and lutein based on hyperspectral imaging. In 2017 ASABE Annual International Meeting. Washington, USA : American Society of Agricultural and Biological Engineers, p. 1-9. https://doi.org/10.13031/aim.201700625

\section{Funds:}

This work was funded by a National Grant for Doctoral Dissertation Research (009/SP2H/AMD/LT-MULTI/ LL4/2020) from the Ministry of Research and Technology and the National Research and Innovation Agency of the Republic of Indonesia. 


\section{Acknowledgments:}

The authors would like to thank Prof. Harijono, Prof. Setyawan Purnomo Sakti, and Dr. Erryana Martati (Universitas Brawijaya) for their insightful advice. We also extend our gratitude to Gita C. Kombaitan for her assistance with pigment separation and the preliminary microbial assay, as well as to Dr. (Cand.) Heriyanto for his helpful discussion concerning the chromatographic analysis.

\section{Conflict of Interest:}

The authors declare no conflict of interest.

\section{Ethical Statement:}

This article does not contain any studies that would require an ethical statement.

\section{Contact Address:}

Renny Indrawati, Universitas Ma Chung, Ma Chung Research Center for Photosynthetic Pigments, VillaPuncak Tidar N-1, 65151, Malang, Indonesia, Tel.: +62341550777, E-mail: renny.indrawati@machung.ac.id

ORCID: https://orcid.org/0000-0003-0682-4126
Elok Zubaidah, Universitas Brawijaya, Faculty of Agricultural Technology, Jalan Veteran, 65145, Malang, Indonesia, Tel.: +62341580106,

E-mail: elok@ub.ac.id

ORCID: https://orcid.org/0000-0002-7405-5632

Aji Sutrisno, Universitas Brawijaya, Faculty of Agricultural Technology, Jalan Veteran, 65145, Malang, Indonesia, Tel.: +62341580106,

E-mail: aji sutrisno@ub.ac.id

ORCID: https://orcid.org/0000-0001-6055-9613

*Leenawaty Limantara, Universitas Pembangunan Jaya, Center for Urban Studies, Jalan Cendrawasih Raya B7/P, 15413, South Tangerang, Indonesia, Tel. +62217455555, E-mail: leenawaty.limantara@upj.ac.id ORCID: https://orcid.org/0000-0002-1786-8178

Tatas Hardo Panintingjati Brotosudarmo, Universitas Ma Chung, Ma Chung Research Center for Photosynthetic Pigments, Villa Puncak Tidar N-1, 65151, Malang, Indonesia, Tel.: +62341550777,

E-mail: tatas.brotosudarmo@machung.ac.id ORCID: $\underline{\text { https://orcid.org/0000-0002-8219-3293 }}$

Corresponding author: * 